\title{
Microbial activities on Trichodesmium colonies
}

\author{
Monika Nausch* \\ Institut für Ostseeforschung, Seestrasse 15, D-18119 Rostock-Warnemünde, Germany
}

\begin{abstract}
During a cruise from 20 May to 19 June 1994 in the tropical North Atlantic Ocean between 30 and $10^{\circ} \mathrm{N}$ and in the Caribbean Sea, heterotrophic bacterial activities on colonies of the filamentous cyanobacterium Trichodesmium spp. were investigated. Thymidine incorporation rates between 0.011 and $0.045 \mathrm{pmol} \mathrm{h}^{-1}$ colony ${ }^{-1}$ and leucine incorporation between 0.007 and $0.332 \mathrm{pmol} \mathrm{h}^{-1}$ colony $^{-1}$ were found. Turnover times of glucose varied between 31 and $267 \mathrm{~d}$ colony ${ }^{-1}$ The hydrolysis rates (Hr) determined at trace concentrations of substrates ranged between 0.88 and $16.92 \% \mathrm{~h}^{-1}$ colony $^{-1}$ for phosphatase activities, between 0.01 and $0.87 \% \mathrm{~h}^{-1}$ colony $^{-1}$ for $\alpha$-glucosidase actuvities, between 0.03 and $1.24 \% \mathrm{~h}^{-1}$ colony $^{-1}$ for $\beta$-glucosidase activities, between 0.02 and $0.58 \% \mathrm{~h}^{-1}$ colony $^{-1}$ for $\beta$-glucosaminidase activity, and between 0.40 and $7.60 \% \mathrm{~h}^{-1}$ colony $y^{-1}$ for leucine peptidase activities, respectively. The quotient of glucose turnover and hydrolysis rate suggests that large quantities of released matter were not taken up by adherent bacteria. Most likely this dissolved material diffuses into the surrounding water and is avallable for free living bacteria. Thymidine incorporation of free living bacteria in surrounding water ranged between 0.977 and $18.49 \mathrm{pmol} \mathrm{h}^{-1} \mathrm{l}^{-1}$ and for leucine incorporation between 21.44 and $127.67 \mathrm{pmol} \mathrm{h} \mathrm{h}^{-1} \mathrm{l}^{-1}$ The turnover time of glucose of free living bacteria was between 24 and $109 \mathrm{~d}$. Since abundance of colones was approximately 7 colonies $1^{-1}$, this indicates that the activity of free living bactena was substantually higher than that of attached bacteria on Trichodesmium colonies in the same volume of water
\end{abstract}

KEY WORDS: Trichodesmium - Cyanobacteria - Bacterial degradation - Thymidine incorporation · Leucine incorporation Extracellular enzyme activity

\section{INTRODUCTION}

The diazotrophic, bloom forming cyanobacterium Trichodesmium spp. is common in the euphotic zone of oligotrophic regions of tropical and subtropical oceans. Trichodesmium spp. are capable of $\mathrm{N}_{2}$-fixation in the light under aerobic conditions. The nitrogen input by $\mathrm{N}_{2}$-fixation of Trichodesmium comprises a quarter of the annual $\mathrm{N}_{2}$-fixation of the ocean (Ohuki \& Fujita 1988, Capone et al. 1990, Bergman \& Carpenter 1991, Paerl et al. 1994). In the tropical North Atlantic Ocean (south of $30^{\circ} \mathrm{N}$ ) and in the Caribbean Sea, the largest part of $\mathrm{N}$ - and C-input is caused by Trichodesmium. During different cruises and in different seasons between 1000 and 5500 Trichodesmium colonies $\mathrm{m}^{-3}$ were counted, which constituted approximately $61 \%$ of the total biomass (Carpenter \& Price 1977, Carpenter \& Romans 1991). Trichodesmium colonies caused a

\footnotetext{
-E-mail: monika.nausch@io-warnemuende.de
}

nitrogen input of 10 to $50 \mathrm{mg} \mathrm{N} \mathrm{m} \mathrm{N}^{-2} \mathrm{~d}^{-1}$ by $\mathrm{N}_{2}$-fixation and a carbon input of 55 to $275 \mathrm{mg} \mathrm{C} \mathrm{m}^{-2} \mathrm{~d}^{-1}$ (Carpenter \& Romans 1991).

Two different morphological types of Trichodesmium colonies can be found in natural samples: a filamentous type (tufts) and a spherical type (puffs). According to Borstad et al. (1993), the colonies can change their structure from tufts to puffs. In contrast to other phytoplankton blooms, it seems that Trichodesmium colonies do not sink to deeper layers (Pomeroy \& Wiebe 1993). The highest abundances of colonies were counted in surface layers between 10 and $50 \mathrm{~m}$. Below $150 \mathrm{~m}$ no Trichodesmium colonies were found (Carpenter \& Price 1977). From these observations it can be concluded that substantial degradation of colonies occurs in the surface layer of the water column. During degradation of colonies part of the nitrogen bound by $\mathrm{N}_{2}$ fixation will be transferred to the pool of dissolved nitrogen and can be used by other autotrophic and heterotrophic organisms (Carpenter \& Price 1977). 
Dense bacterial colonization of around 50000 bacteria per. Trichodesmium colony were observed (Siddiqui et al. 1993), but very little is known about the nature of these bacteria (Zehr 1995). Bacteria are attached to the trichomes and also to the mucopolysaccarid layer surrounding the trichomes (Borstad 1978, Paerl et al. 1989). It has been proposed that the mucopolysaccarid layer has the function to protect the trichomes against the direct degradation by heterotrophic bacteria and may help to keep the trichomes in a colonial form (O'Neil \& Roman 1992). On the other hand, bacteria may prevent the aggregation of phytoplankton by enzymatic degradation of the mucopolysaccarid layer (Azam \& Smith 1991, Smith et al. 1995). According to observations of Borstad (1978), the attachment of bacteria to colonies is a characteristic feature of senescence, but these observations could not be confirmed by Paerl et al. (1989). They found that Trichodesmium colonies are densely colonized by bacteria during intense photosynthesis. Since bacteria are the main agents for degradation of particulate matter and the release of dissolved substances (Cho \& Azam. 1990, Azam \& Smith 1991, Azam et al. 1992. Turley 1992), the colonization of Trichodesmium colonies may indicate an important transformation of organic matter produced by the cyanobacteria.

For the unproductive tropical and subtropical regions of the Atlantic Ocean there are only few data available about the activities of bacteria associated with particles and in the surrounding water The aim of this study was to investigate in detail the bacterial processes within Trichodesmium colonies.

\section{METHODS}

Trichodesmium spp. colonies were collected during the cruise with the RV 'Gyre' from 20 May to 19 June 1994 in the Atlantic Ocean between 30 and $10^{\circ} \mathrm{N}$ and in the Caribbean Sea (Fig 1). Colonies were collected by net tows (mesh size $243 \mu \mathrm{m}$ ) in depths between 10 and $30 \mathrm{~m}$ and individually picked up and transferred into $0.2 \mu \mathrm{m}$ (sterile) filtered seawater by an inoculating loop.

Water samples for bacterial counts and estimation of cell volumes were preserved with $0.5 \%$ formaldehyde. Subsamples of $10 \mathrm{ml}$ were filtered onto $0.2 \mu \mathrm{m}$ black Nuclepore filters, stained with 4,6-diamidino-2-phenyl-indol (DAPI) solution. for 5 min and mounted in immersion oil. Cells were counted and sized with an epifluorescence microscope (Zeiss) and an image analysis system (Photometrics) (Psenner 1993). Biomass calculations were performed as in Simon \& Azam (1989) using the size dependent carbon content of bacterial cells.

Scanning electron microscopic investigations were performed with a CAM SCAN 44 'Analytic WEX' Trichodesmium colonies were fixed with $0.3 \%$ formaldehyde, dehydrated in a concentration series of ethanol (20 to $100 \%$ ) and acetone, critical point dried and sputtered with gold.

Bacterial production was estimated by thymidine and leucine incorporation (Fuhrman \& Azam 1982, Bell 1993, Kirchman 1993) with the 'dual label' method as in Chin-Leo \& Kirchman (1988), Jonas et al. (1988), Simon et al. (1990) and Kirchman et al. (1993). Twenty colonies were transferred into $10 \mathrm{ml}$ sterile filtered seawater containing ${ }^{3} \mathrm{H}$-thymidine (Amersham, spec. activity $5 \mathrm{Ci} \mathrm{mmol}^{-1}$ ) at a final concentration of $10 \mathrm{nM}$ and ${ }^{14} \mathrm{C}$-leucine (Amersham, spec, activity $300 \mathrm{mCi}$ $\mathrm{mmol}^{-1}$ ) at a final concentration of $100 \mathrm{nM}$. These samples were incubated in $20 \mathrm{ml}$ plastic vials in the dark at in situ temperatures. After $2 \mathrm{~h}$ incubations they were stopped with $0.3 \%$ formaldehyde final concentration. Determinations were carried out in triplicate; formaldehyde prekilled samples were used as blanks. Samples were filtered onto $0.2 \mu \mathrm{m}$ cellulose nitrate filters, rinsed 10 times with $1 \mathrm{ml} \mathrm{5 \%}$ ice-cold trichloroacetic acid and radioassayed on board in an LKB Wallac liquid scintillation counter, using Ultima-gold XR (Packard) scintillation cocktail.

Thymidine and leucine incorporation of colonies was calculated as in Alldredge (1993):

$$
\text { mol h }{ }^{-1} \text { colony } y^{-1}=(\mathrm{dpm})\left(S A^{-1}\right)\left(4.5 \times 10^{-13}\right) /(N)(t)
$$

where $S A$ is specific activity of radioisotope solution (Ci mol ${ }^{-1}$ ); $4.5 \times 10^{-13}=\mathrm{Ci} \mathrm{dpm}^{-1}$; $N$ is number of aggregates; $t$ is incubation time; and dpm (disintegration per minute) is activity in the sample

For the estimation of bacterial production of free living bacteria, $20 \mathrm{ml}$ of water sample were incubated

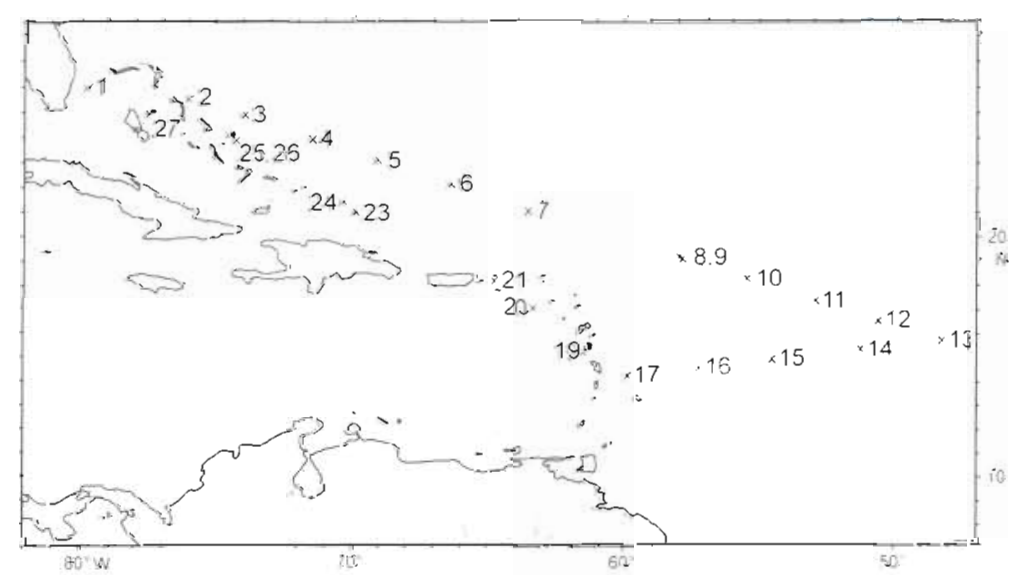

Fig. 1. Location of sampling stations during the cruise with RV 'Gyre' in May and June 1994 
with $5 \mathrm{nM}{ }^{3} \mathrm{H}$-thymidine and $50 \mathrm{nM}{ }^{14} \mathrm{C}$-leucine as described above. Water samples were collected in $10 \mathrm{~m}$ depth with a rosette sampler. The bacterial biomass production was calculated from leucine incorporation using a conversation factor of $3.1 \mathrm{~kg} \mathrm{C} \mathrm{mol}^{-1}$ (Kirchman. 1993).

For the determination of uptake of natural substrates (Gocke 1977. Güde 1988) the turnover rate (\% $\mathrm{h}^{-1}$ colony ${ }^{-1}$ ) of ${ }^{14} \mathrm{C}$-glucose was measured. ${ }^{14} \mathrm{C}$-glucose (Amersham, spec. activity $300 \mathrm{mCi} \mathrm{mmol}^{-1}$ ) was added to 20 colonies in $10 \mathrm{ml}$ sterile filtered seawater in concentrations of $33 \mathrm{nM}$ and incubated as described above.

Bacterial extracellular enzyme activities on Trichodesmium colonies were determined according to the methods of Hoppe $(1983,1991,1993)$. For the measurement of the hydrolysis rate $(\mathrm{Hr})$ the following substrates were added. 4-methylumbelliferyl-(MUF)phosphate, MUF- $\alpha$ - and MUF- $\beta$-glucoside, MUF-Nacetyl- $\beta$-glucosaminide, and leucine-methylcoumarinylaminide (leucine-MCA). All substrates were added in trace amounts of $50 \mathrm{nM}$ except MUF- $\alpha$-glucoside $(100 \mathrm{nM})$ for the estimation of in situ hydrolysis of natural substrates. Tests showed that substrate saturation was reached at $12.5 \mu \mathrm{M}$ for $\alpha$-glucoside. The other substrates reached saturation concentrations at $50 \mu \mathrm{M}$. For each experiment 6 colonies were incubated in $1 \mathrm{ml}$ sterile filtered seawater in the dark at in situ temperatures. Fluorescence readings were performed with a KONTRON-spectrofluorometer SFM 25 at $364 \mathrm{~nm}$ excitation and $445 \mathrm{~nm}$ emission. Calibration was performed with standard solutions of 4-methylumbelliferone and 7 -amino-4-methylcoumarin in a range between 0.01 and $1.0 \mu \mathrm{mol} \mathrm{l^{-1 }}$

For measurements of particulate organic carbon (POC) and nitrogen (PON) Trichodesmium colonies were collected on Whatman GF/F filters, which were precombusted at a temperature of $450^{\circ} \mathrm{C}$. The samples on the filters were stored at $-20^{\circ} \mathrm{C}$ until analysis in a CHNanalyser 'O-Rapid' (Haereus).

\section{RESULTS}

Trichodesmium colonies can be divided into sinkers and floaters. According to investigations of Romans et al. (1994), sinkers contain more carbohydrates than floaters. For this reason the colonies were separated at the first 2 stations into sinkers and floaters. However, sinkers and floaters did not show large differences particularly with respect to enzyme activities.
Microscopic observations on board revealed that the trichomes of puffs were imbedded in mucopolysaccharides more strongly than those of tufts. Since this may affect bacterial activity, at the following stations the filamentous colonies (tufts) were separated from the spheric colonies (puffs). The colonization of Trichodesmium trichomes by bacteria observed by scanning electron microscopy showed coccoid and rod shaped bacteria attached to the trichomes (Fig. 2). In the mucus between the trichomes rod shaped bacteria seemed to dominate

Thymidine and leucine incorporation in the whole area (except Stn 9) ranged between 0.011 and 0.045 pmol thymidine $h^{-1}$ colony $^{-1}$ and between 0.077 and 0.322 pmol leucine $\mathrm{h}^{-1}$ colony $\mathrm{y}^{-1}$ (Fig. 3). Only at Stn 9 was incorporation substantially higher for thymidine $10.155 \mathrm{pmol} \mathrm{h}^{-1}$ colony $^{-1}$ for tufts and $0.184 \mathrm{pmol}$. $\mathrm{h}^{-1}$ colony $^{-1}$ for puffs) and leucine $\left(0.69 \mathrm{pmol} \mathrm{h}^{-1}\right.$ colony $^{-1}$ for tufts and $0.45 \mathrm{pmol} \mathrm{h}^{-1}$ colony $^{-1}$ for puffs). At this station, the other parameters investigated were also higher than at the other stations. There was a significant correlation between thymidine and leucine incorporation ( $\mathrm{r}=0.72 ; \mathrm{p}=0.01$ ). At some stations the thymidine incorporation was higher for tufts than for puffs; at other stations no differences could be observed. Leucine incorporation by puffs was generally lower than by tufts. On average leucine incorporation by tufts was twice that of puffs (Table 1).

The estimation of turnover of natural substrates via ${ }^{14} \mathrm{C}$-glucose showed that at most of the stations less than $0.05 \% \mathrm{~h}^{-1}$ colony $\mathrm{y}^{-1}$ of substrates were utilized (Table 1). Correspondingly the turnover times of glucose were very long: on average $142 \mathrm{~d}$. This indicates that only very small amounts of material were taken up

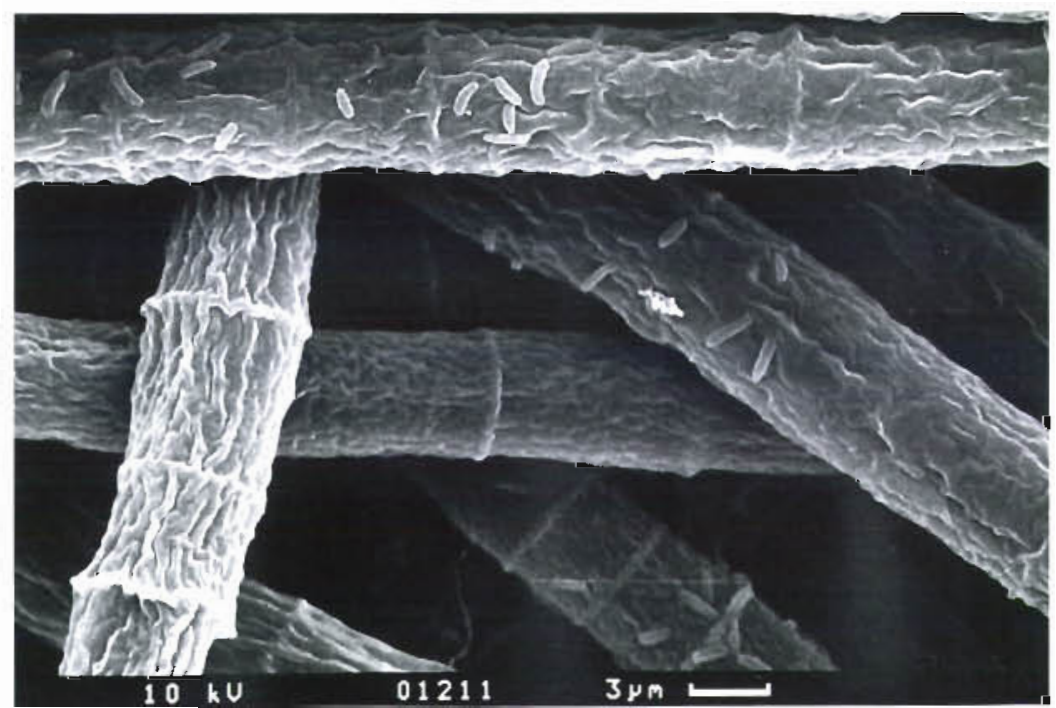

Fig. 2. Rod shaped bacteria associated with Trichodesmium trichomes (scanning electron micrograph) (R. Bahlo, Baltic Sea Research Institute, pers. comm.) 


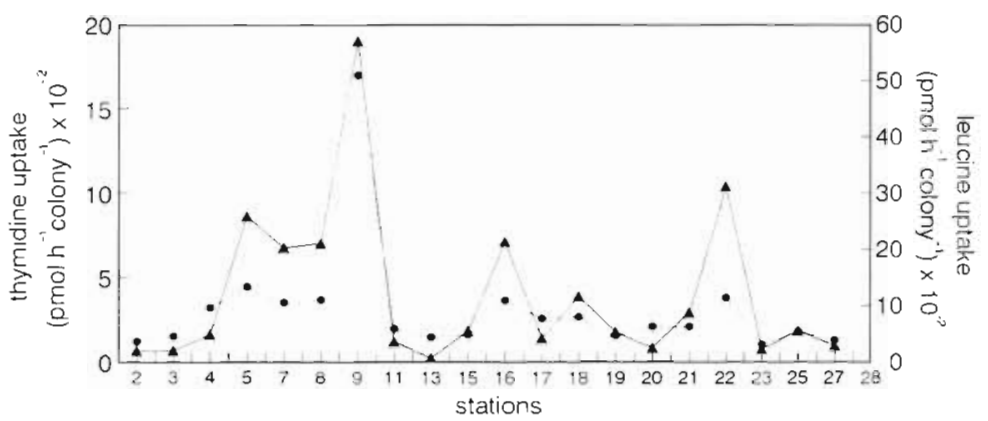

Fig. 3. Thymidine and leucine incorporation of Trichodesmium colonies at the stations (values are averagcd for each station). (-) thymidine uptake (₫) leucine uptake

by bacteria on Trichodesmium colonies. Table 1 shows that similar spatial trends as those found for bacterial production apply for glucose turnover rates, causing a significant correlation $(\mathrm{r}=0.94 ; \mathrm{p}=0.01)$ between $\mathrm{glu}-$ cose turnover and bacterial production. No significant differences between glucose turnover of tufts and puffs could be detected.

At some selected stations bacterial counts, biomass, production and glucose turnover of free living bacteria in the surrounding water at a depth of $10 \mathrm{~m}$ were determined (Table 2). Thymidine incorporation ranged between 0.98 and $18.49 \mathrm{pmol} \mathrm{h}^{-1} \mathrm{l}^{-1}$; leucine incorporation ranged between 21.44 and $127.62 \mathrm{pmol} \mathrm{h}^{-1} \mathrm{l}^{-1}$ The glucose turnover of free living bacteria ranged be- tween 0.04 and $0.18 \% \mathrm{~h}^{-1} \mathrm{l}^{-1}$, corresponding to an average turnover time of $49 \mathrm{~d}$. No correlation was found between bacterial activities in the surrounding water and on Trichodesmium colonies at different stations. During the cruise, on average $7 \mathrm{col}$ onies $\mathrm{l}^{-1}$ were counted (E. J. Carpenter pers. comm.). The bacterial production on these colonies amounted to only $1-2 \%$ of the bacterial production of free living bacteria in the water. On the other hand the glucose turnover of bacteria on 7 colonies $l^{-1}$ had the same range as that measured for the free living bacteria in $1 \mathrm{l}$ of water The hydrolysis rate of extracellular enzymes ( $\mathrm{Hr}$ ) for all substrates on average was higher for tufts than for puffs at many stations (Table 3). For the activities of enzymes the following sequence was found for tufts as well as for puffs: phosphatase $>$ peptidase $>\beta$-glucosidase $>\beta$-glucosaminidase $>\alpha$-glucosidase (Table 3 ) . There was a significant correlation $(r=0.61 ; p=0.05)$ between hydrolysis rate through peptidase and leucine incorporation (Fig. 4). The glucose turnover showed a significant correlation with the hydrolysis of $\alpha$-glucoside $(r=0.69 ; p=0.05)$, but not with $\beta$-glucoside (Fig. 5). The quotient between glucose turnover and the hydrolysis of carbohydrates ( $\mathrm{Tr} / \mathrm{Hr}$ ) varied between 0.01 and 0.29 .

Table 1 Thymidine and leucine incorporation as well as turnover rate and turnover time of glucose in Trichodesmium colonies of sinkers, floaters, tufts and puffs. SD: standard deviation

\begin{tabular}{|c|c|c|c|c|c|c|c|c|c|c|c|c|c|c|}
\hline \multirow[t]{3}{*}{ Stn } & \multicolumn{4}{|c|}{$\begin{array}{l}\text { Thymidine uptake } \\
\left(\mathrm{pmol} \mathrm{h}^{-1} \text { colony }{ }^{-1}\right)\end{array}$} & \multicolumn{4}{|c|}{$\begin{array}{l}\text { Leucine uptake } \\
\left(\text { pmol h }^{-1} \text { colon } y^{-1}\right)\end{array}$} & \multicolumn{4}{|c|}{$\begin{array}{l}\text { Glucose turnover } \\
\left(\% \mathrm{~h}^{-1} \text { colony } y^{-1}\right)\end{array}$} & \multicolumn{2}{|c|}{$\begin{array}{c}\text { Turnover time } \\
\text { (d) }\end{array}$} \\
\hline & \multicolumn{2}{|c|}{ Sinkers } & \multicolumn{2}{|c|}{ Floaters } & \multicolumn{2}{|c|}{ Sinkers } & \multicolumn{2}{|c|}{ Floaters } & \multicolumn{2}{|c|}{ Sinkers } & \multicolumn{2}{|c|}{ Floaters } & \multirow[t]{2}{*}{ Sinkers } & \multirow[t]{2}{*}{ Floaters } \\
\hline & Mean & $\mathrm{SD}$ & Mean & $\mathrm{SD}$ & Mean & $\mathrm{SD}$ & Mean & $\mathrm{SD}$ & Mean & $\mathrm{SD}$ & Mean & $\mathrm{SD}$ & & \\
\hline 3 & 0.013 & 0.003 & 0.018 & 0.001 & 0.021 & 0.020 & 0.019 & 0.008 & 0.020 & 0.002 & 0.023 & 0.005 & 209 & 182 \\
\hline \multirow[t]{3}{*}{4} & 0.038 & 0.002 & 0.026 & 0.002 & 0.052 & 0.019 & 0.045 & 0.020 & 0.041 & 0.001 & 0.022 & 0.004 & 100 & 190 \\
\hline & \multicolumn{2}{|c|}{ Tufts } & \multicolumn{2}{|c|}{ Puffs } & \multicolumn{2}{|c|}{ Tufts } & \multicolumn{2}{|c|}{ Puffs } & \multicolumn{2}{|c|}{ Tufts } & \multicolumn{2}{|c|}{ Puffs } & Tufts & Puffs \\
\hline & Mean & SD & Mean & $\mathrm{SD}$ & Mean & $\mathrm{SD}$ & Mean & $\mathrm{SD}$ & Mean & $\mathrm{SD}$ & Mean & $\mathrm{SD}$ & & \\
\hline 7 & 0.034 & 0.001 & 0.036 & 0.004 & 0.272 & 0.016 & 0.133 & 0.033 & 0.041 & 0.005 & 0.049 & 0.008 & 102 & 85 \\
\hline 8 & 0.037 & 0.001 & & & 0.210 & 0.014 & & & & & & & & \\
\hline 9 & 0.156 & 0.072 & 0.184 & 0.018 & 0.699 & 0.410 & 0.452 & 0.206 & 0.127 & 0.007 & 0.133 & 0.029 & 33 & 31 \\
\hline 11 & & & 0.020 & 0.002 & & & 0.036 & 0.013 & & & 0.028 & 0.003 & & 222 \\
\hline 13 & & & 0.015 & 0.001 & & & 0.007 & 0.002 & & & 0.018 & 0.002 & & 229 \\
\hline 15 & 0.016 & 0.001 & & & 0.055 & 0.017 & & & 0.033 & 0.008 & & & 127 & \\
\hline 16 & 0.041 & 0.010 & 0.032 & 0.001 & 0.597 & 0.503 & 0.045 & 0.019 & 0.029 & 0.007 & 0.031 & 0.001 & 141 & 135 \\
\hline 17 & & & 0.026 & 0.002 & & & 0.042 & 0.003 & & & 0.025 & 0.003 & & 161 \\
\hline 18 & 0.028 & 0.004 & & & 0.116 & 0.049 & & & 0.021 & 0.005 & & & 196 & \\
\hline 19 & 0.016 & 0.002 & & & 0.053 & 0.035 & & & 0.015 & 0.001 & & & 267 & \\
\hline 20 & 0.025 & 0.004 & 0.017 & 0.002 & 0.302 & 0.149 & 0.026 & 0.006 & 0.019 & 0.001 & 0.022 & 0.002 & 217 & 186 \\
\hline 21 & 0.021 & 0.003 & & & 0.082 & 0.043 & & & 0.028 & 0.009 & & & 149 & \\
\hline & 0.045 & 0.003 & 0.030 & 0.005 & 0.302 & 0.160 & 0.322 & 0.173 & 0.05 & 0.021 & 0.031 & 0.007 & 83 & 135 \\
\hline 23 & 0.011 & 0.001 & & & 0.023 & 0.004 & & & 0.024 & 0.003 & & & 174 & \\
\hline 25 & 0.018 & 0.002 & & & 0.055 & 0.025 & & & 0.047 & & & & 87 & \\
\hline 27 & 0.013 & 0.001 & & & 0.029 & 0.020 & & & 0.053 & 0.009 & & & 79 & \\
\hline
\end{tabular}


Table 2. Bacterial counts, production and glucose turnover of free living bacteria in the water at $10 \mathrm{~m}$ depth at selected stations. Bacterial production was calculated using a conversion factor from Kirchman (1993). SD: standard deviation; nd: not determined

\begin{tabular}{|c|c|c|c|c|c|c|c|c|c|c|}
\hline \multirow[t]{2}{*}{$\operatorname{Stn}$} & \multirow[t]{2}{*}{$\begin{array}{c}\text { Bacterial } \\
\text { counts } \\
\left(\times 10^{6} \mathrm{l}^{-1}\right)\end{array}$} & \multirow[t]{2}{*}{$\begin{array}{c}\text { Bacterial } \\
\text { biomass } \\
\left(\mu g \mathrm{Cl}^{-1}\right)\end{array}$} & \multicolumn{2}{|c|}{$\begin{array}{c}\text { Thymidine } \\
\text { uptake } \\
\left(\text { pmol } h^{-1} \mathrm{l}^{-1}\right)\end{array}$} & \multicolumn{2}{|c|}{$\begin{array}{c}\text { Leucine } \\
\text { uptake } \\
\left(\text { pmol }^{-1} \mathrm{l}^{-1}\right)\end{array}$} & \multirow[t]{2}{*}{$\begin{array}{c}\text { Biomass } \\
\text { production } \\
\left(\text { ng } C n^{-1} l^{-1}\right)\end{array}$} & \multicolumn{2}{|c|}{$\begin{array}{c}\text { Glucose } \\
\text { turnover } \\
\left(\% \mathrm{~h}^{-1}\right)\end{array}$} & \multirow[t]{2}{*}{$\begin{array}{c}\text { Turnover } \\
\text { time } \\
\text { (d) }\end{array}$} \\
\hline & & & Mean & $\mathrm{SD}$ & Mean & $\mathrm{SD}$ & & Mean & SD & \\
\hline 5 & 348 & 35.7 & 11.62 & 0.06 & 42.75 & 11.41 & 132.13 & 0.04 & 0.007 & 103 \\
\hline 6 & 608 & 64.8 & 1.66 & 0.01 & nd & nd & & 0.04 & 0.005 & 109 \\
\hline 10 & 175 & & 5.37 & 0.03 & 21.44 & 5.72 & 66.27 & 0.04 & 0.007 & 37 \\
\hline 13 & 411 & 52.5 & 18.49 & 0.11 & 127.62 & 34.08 & 394.49 & 0.12 & 0.006 & 37 \\
\hline 16 & 696 & 93.1 & 13.88 & 0.08 & 68.48 & 18.29 & 211.69 & 0.18 & 0.015 & 28 \\
\hline 19 & 528 & 54.8 & 11.15 & 0.06 & 68.38 & 18.26 & 211.36 & 0.18 & 0.030 & 23 \\
\hline 25 & 540 & 63.6 & 10.67 & 0.06 & 35.54 & 9.49 & 109.85 & 0.14 & 0.027 & 30 \\
\hline 27 & nd & nd & 0.98 & 0.01 & nd & nd & & 0.17 & 0.009 & 24 \\
\hline
\end{tabular}

Table 3. Hydrolysis rate $\left(\mathrm{Hr}\right.$, in $\% \mathrm{~h}^{-1}$ colony $^{-1}$ ) of extracellular enzyme activities of bacteria associated with Trichodesmium colonies. SD: standard deviation

\begin{tabular}{|c|c|c|c|c|c|c|c|c|c|c|}
\hline \multirow[t]{3}{*}{$\operatorname{Sin}$} & \multicolumn{2}{|c|}{$\begin{array}{c}\text { Phosphatase } \\
\text { activity }\end{array}$} & \multicolumn{2}{|c|}{$\begin{array}{l}\alpha \text {-glucosidase } \\
\text { activity }\end{array}$} & \multicolumn{2}{|c|}{$\begin{array}{c}\beta \text {-glucosidase } \\
\text { activity }\end{array}$} & \multicolumn{2}{|c|}{$\begin{array}{c}\beta \text {-glucosaminidase } \\
\text { activity }\end{array}$} & \multicolumn{2}{|c|}{$\begin{array}{l}\text { Peptidase } \\
\text { activity }\end{array}$} \\
\hline & Floaters & Sinkers & Floaters & Sinkers & Floaters & Sinkers & Floaters & Sinkers & Floaters & Sinkers \\
\hline & Mean SD & Mean SD & Mean SD & Mean SD & Mean SD & Mean SD & Mean SD & Mean SD & Mean SD & Mean SD \\
\hline 1 & $2.20 \quad 1.40$ & $3.60 \quad 1.60$ & 0.010 .01 & $0.03 \quad 0.01$ & $0.42 \quad 0.3$ & $0.03 \quad 0.01$ & $0.02 \quad 0.02$ & $0.12 \quad 0.12$ & $2.60 \quad 0.86$ & $0.40 \quad 0.10$ \\
\hline 2 & $4.80 \quad 2.10$ & $3.00 \quad 0.88$ & $0.05 \quad 0.04$ & $0.02 \quad 0.01$ & $0.60 \quad 0.60$ & 0.120 .05 & $0.04 \quad 0.02$ & $0.18 \quad 0.06$ & $2.00 \quad 1.2$ & $2.64 \quad 0.08$ \\
\hline 3 & $\begin{array}{lll}3.80 & 1.12\end{array}$ & & $0.04 \quad 0.03$ & & $0.20 \quad 0.12$ & & $0.18 \quad 0.12$ & & $0.40 \quad 0.22$ & \\
\hline \multirow[t]{3}{*}{4} & $3.80 \quad 1.40$ & & $0.03 \quad 0.02$ & & $0.16 \quad 0.12$ & & & & $0.50 \quad 0.24$ & \\
\hline & Tufts & Puffs & Tufts & Puffs & Tufts & Puffs & Tufts & Puffs & Tufts & Puffs \\
\hline & Mean SD & Mean SD & Mean SD & Mean SD & Mean SD & Mean SD & Mean SD & Mean SD & Mean SD & Mean SD \\
\hline 7 & $22.16 \quad 10.4$ & $\begin{array}{ll}5.56 & 2.32\end{array}$ & $0.28 \quad 0.26$ & $0.27 \quad 0.04$ & $0.44 \quad 0.08$ & $0.66 \quad 0.10$ & $0.30 \quad 0.04$ & $0.14 \quad 0.08$ & $\begin{array}{lll}7.60 & 0.22\end{array}$ & $3.46 \quad 1.48$ \\
\hline 10 & $5.62 \quad 2.52$ & $4.42 \quad 1.86$ & 0.190 .14 & 0.170 .06 & $\begin{array}{lll}0.32 & 0.22\end{array}$ & $0.22 \quad 0.12$ & $0.48 \quad 0.22$ & $0.34 \quad 0.12$ & $3.26 \quad 1.46$ & $1.86 \quad 0.46$ \\
\hline 19 & $19.60 \quad 4.46$ & $11.36 \quad 2.34$ & 0.230 .07 & $0.10 \quad 0.06$ & $0.24 \quad 0.1$ & $0.15 \quad 0.06$ & $0.23 \quad 0.04$ & $0.04 \quad 0.04$ & 3.600 .46 & $1.68 \quad 1.16$ \\
\hline \multirow[t]{2}{*}{21} & $11.88 \quad 1.82$ & $16.36 \quad 4.26$ & $0.13 \quad 0.02$ & 0.120 .06 & 0.900 .56 & $\begin{array}{lll}0.32 & 0.12\end{array}$ & 0.580 .58 & $0.38 \quad 0.20$ & $5.00 \quad 1.64$ & 1.160 .46 \\
\hline & $5.12 \quad 3.2$ & $10.02 \quad 1.9$ & $0.08 \quad 0.02$ & $0.14 \quad 0.10$ & 0.820 .42 & $0.24 \quad 0.08$ & 0.200 .16 & $0.08 \quad 0.02$ & $3.70 \quad 1.62$ & $1.14 \quad 0.02$ \\
\hline 23 & $10.32 \quad 1.54$ & $5.54 \quad 0.90$ & $0.09 \quad 0.06$ & $0.18 \quad 0.10$ & $\begin{array}{lll}0.96 & 0.22\end{array}$ & $0.88 \quad 0.44$ & 0.280 .28 & $0.16 \quad 0.12$ & $1.14 \quad 0.78$ & $1.02 \quad 0.26$ \\
\hline 25 & $16.92 \quad 1.96$ & & 0.550 .41 & & $1.04 \quad 0.46$ & & 0.100 .06 & & $3.22 \quad 0.34$ & \\
\hline 26 & $13.78 \quad 1.26$ & & $0.87 \quad 0.40$ & & $1.24 \quad 0.54$ & & 0.320 .26 & & $2.36 \quad 0.86$ & \\
\hline
\end{tabular}

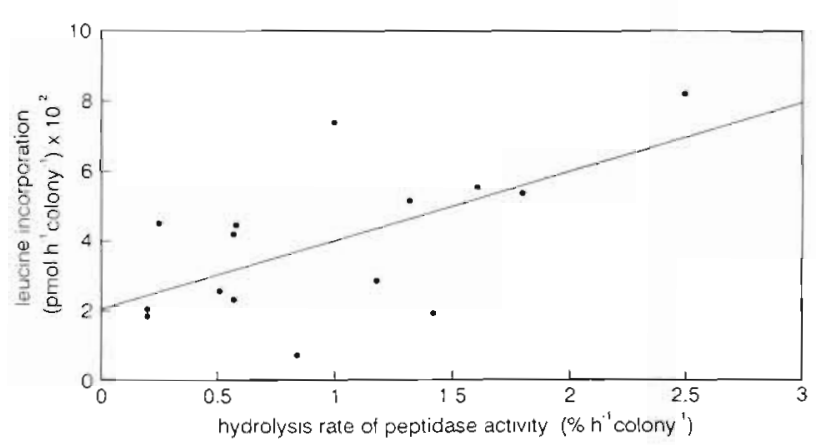

Fig. 4. Correlation $(y=1.95 x+2.05, r=0.61, n=15, p=0.05)$ between hydrolysis of proteins and leucine incorporation of bacteria associated with Trichodesmium colonies, high value at $\operatorname{Stn} 9$ excluded

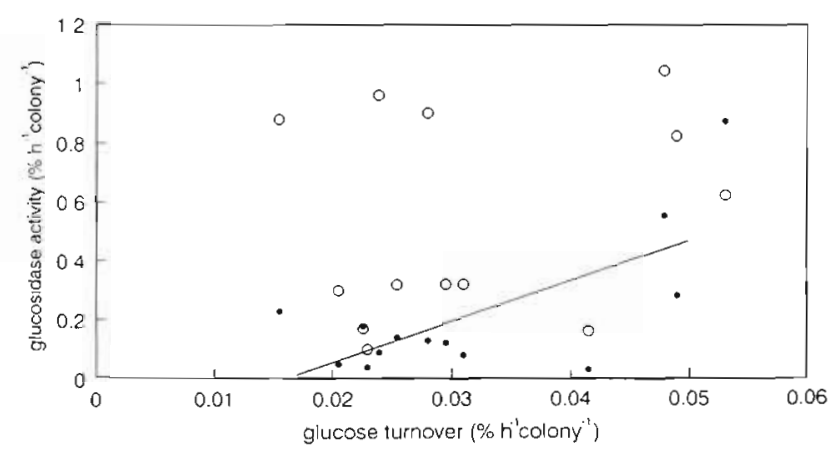

Fig. 5. Correlation between glucose turnover and hydrolysis rates of carbohydrates by $\alpha$ - and $\beta$-glucosidases: $\alpha$-glucos. $y=13.69 x-0.22, r=0.69, n=13, p=0.01 ; \beta$-glucos : no correlation; $(\bullet$-glucosidase; (0) $\beta$-glucosidase 
The POC content of freshly isolated Trichodesmium colonies ranged between 4.0 and $21.8 \mu \mathrm{g} \mathrm{C}$ colony ${ }^{-1}$, on average $9.1 \mu \mathrm{g} \mathrm{C}$ colony ${ }^{-1}$ PON values varied between 0.7 and $3.8 \mu \mathrm{g} \mathrm{N}$ colony $^{-1}$, on average $1.6 \mu \mathrm{g} \mathrm{N}$ colony $y^{-1}$. The $C / N$ ratio was relatively constant between 4.5 and 6.9 , on average 5.7 .

\section{DISCUSSION}

Bacterial activities determined on Trichodesmium colonies can be influenced by the following factors related to colony morphology:

(1) Trichodesmium colonies consist of different numbers of trichomes.

(2) Trichomes in colonies have a different compactness causing different sizes of free spaces which are suitable for settlement of microorganisms.

(3) Trichodesmium colonies are embedded in a mucopolysaccharide layer which is a habitat for microorganisms. This mucopolysaccharide layer is differently developed in the colonies.

(4) Not only Trichodesmium colonies and the adherent bacteria were transferred into $0.2 \mu \mathrm{m}$ filtered seawater, but also other organisms associated with the colonies, for instance bacteriovorous protozoa.

In this investigation the thymidine incorporation rates of bacteria on Trichodesmium colonies had the same range as those found by Alldredge et al. (1986) and Alldredge (1993) for marine snow in the southern North Atlantic. It has to be kept in mind, however, that marine snow particles mainly consist of detritus and only a few living algal cells, while Trichodesmium colonies are dominated by living, photosynthetically active cells. The high values at Stn 9 cannot be explained by environmental variables like temperature, salinity or chlorophyll fluorescence, Possible factors which could influence the measured bacterial activities on Trichodesmium colonies are the size and age of colonies, the bacterial populations which colonize them, as well as grazers of bacteria. According to Zehr (1995) the extent of bacterial colonization and the physiological state of Trichodesmium colonies may interact. These factors may be responsible for strong variations; however, we have no means to determine the physiological state of Trichodesmium colonies under natural conditions

During our cruise the bacterial production in $1 \mathrm{I}$ water was higher than that of bacteria on colonies contained in this volume. The biomass production of bacteria associated with Trichodesmium colonies using the conversion factor from Kirchman (1993) ranged between 0.07 and $2.17 \mathrm{ng} \mathrm{C} \mathrm{h}^{-1}$ colony $^{-1}$ or between 0.49 and $15.19 \mathrm{ng} \mathrm{C} \mathrm{h} \mathrm{h}^{-1}$ for 7 colonies in 11 of water. Using the same conversion factor, the bacterial pro- duction of free living bacteria ranged between 21.44 and $211.69 \mathrm{ng} \mathrm{C} \mathrm{h} \mathrm{h}^{-1} \mathrm{l}^{-1}$. These observations of higher activity of the bulk of free living bacteria compared to the attached ones are corroborated by observations of Alldredge et al. (1986) and Alldredge (1993). Aggregates are inhabited by bacteria with abundances 2 to 5 times higher than in an equivalent volume of water. Nevertheless, through the low abundance of aggregates the number of attached bacteria represented only 0.1 to $4.4 \%$ of the total number of bacteria in the surface water of the North Atlantic. In Antarctic regions of the Atlantic Ocean about $20 \%$ of bacteria were associated with particles (Delille 1993), and in Chesapeake Bay less than $10 \%$ were found on particles (Griffith et al. 1994). On the basis of high ${ }^{14} \mathrm{C}$ glucose uptake and low ${ }^{3} \mathrm{H}$-thymidine incorporation, Kirchman (1983) concluded that bacteria on particles have a high metabolism but a low frequency of cell division. This is in accordance with our observations that in $1 \mathrm{l}$ of water bacteria on Trichodesmium colonies had the same range of glucose turnover but a lower ${ }^{3} \mathrm{H}$-thymidine incorporation than free living bacteria, indicating that Kirchman's (1983) conclusions may also be applicable to these colonies.

Colonization of Trichodesmium with microorganisms was previously described by O'Neil \& Roman (1992), and Siddiqui et al. (1993). According to Carpenter \& Price (1977) up to $8.3 \%$ (<1 to $8.3 \%$ ) of Trichodesmium trichomes are populated with bacteria. Major groups of attached bacteria were identified as flavobacteria, enterics and $\beta$-proteobacteria (Zehr 1995).

Alldredge (1993) discussed possibilities which may cause an underestimation of bacterial production on aggregates. One possibility is that the coupling of hydrolysis and uptake is so tight that no organic substances will be taken up from the surrounding water. Since in our investigations there was a correlation between hydrolysis of polypeptides or carbohydrates and the uptake amino acids or monosaccharides, we have to assume that the substrate uptake from the surrounding water was not prevented. Another possibility of underestimation is that caused by the density of trichomes. The diffusion of radioisotopes inside the colonies may be hindered, or dilution of radioisotopes may occur due to the release of dissolved organic matter from Trichodesmium cells. According to Capone et al. (1994) about $2 \mathrm{nmol} \mathrm{d}^{-1}$ colony $^{-1}$ glutamate and glutamine may be released by exudation from Trichodesmium colonies. The lower bacterial activities of puffs relative to tufts of most of measured bacterial variables and the observation of higher mucus content of puffs suggest that the diffusion of added radioactive and fluorogenic substrates may be inhibited to a certain degree. An underestimation of our results cannot be completely excluded. However, since 
bacterial production on colonies in general was lower by at least 1 order of magnitude compared to that of free living bacteria, the underestimation would have to be extremely high to change the conclusion that most activity was associated with free living bacteria.

Bacteria can only take up dissolved organic substances with low molecular weight; thus they hydrolyse high molecular weight substances by means of extracellular enzymes (Hoppe et al. 1988, Münster 1991, Overbeck 1991, Hoppe 1993). Only a small part of phosphatase activity is attributed to bacteria (Chrost 1991, Wetzel 1991) as it will be produced predominantly by phytoplankton if phosphate is limiting. The other enzyme activities are mainly associated with heterotrophic bacteria. The hydrolysis rates of substrates by extracellular enzymes is directly dependent on the pool of substrates and reflects the turnover of natural substrates. The quotient between substrate turnover and hydrolysis rate ( $\mathrm{Tr} / \mathrm{Hr}$ ) describes the coupling between substrate hydrolysis and substrate uptake by bacteria (Hoppe et al. 1988, Hoppe 1991). A low $\mathrm{Tr} / \mathrm{Hr}$ quotient may indicate that the hydrolysed substrates were not completely used by attached bacteria. Therefore, it can be assumed that a large portion diffuses into the surrounding water. A comparison of the hydrolysis rates of $\alpha$ - and $\beta$-glucosides for 7 colonies in $1 \mathrm{l}$ of water $\left(1.70 \% \mathrm{~h}^{-1}\right.$ for $\alpha$-glucosides and $4.21 \% \mathrm{~h}^{-1}$ for $\beta$-glucosides) and the glucose turnover of attached and free living bacteria in the same volume $10.28 \% \mathrm{~h}^{-1}$ and $0.11 \% \mathrm{~h}^{-1}$, respectively) could demonstrate that only small parts of released substrates were taken up. This phenomenon of a loose connection between hydrolysis of high molecular weight substances and the uptake of low molecular weight substances by particle associated bacteria has also been described by Azam \& Smith (1991), Smith et al. $(1992,1995)$ and Middelboe et al. (1995). With respect to free living bacteria, Chrost \& Overbeck (1990) found a close coupling between the heterotrophic activity and the activity of $\beta$-glucosidase in limnic biotopes. In this investigation a correlation exists between hydrolysis of $\alpha$-glucose and glucose turnover of attached bacteria. This indicates a partial coupling between substrate hydrolysis and substrate turnover by attached bacteria. According to Hoppe et al. (1988) in a balanced system there is an equilibrium between the release of monomers through enzymes and the uptake by bacteria. In an imbalanced system more monomers are produced than can be taken up by bacteria, causing a transient increase of low molecular substances in the dissolved organic carbon (DOC) pool. This was derived from a double labeling experiment with leucine-MCA as a peptide analogue and ${ }^{3} \mathrm{H}$-leucine as the corresponding product of peptide hydrolysis.
Organic carbon will be released by glucosidase and peptidase activity, organic nitrogen by peptidase and $\beta$-glucosaminidase activity. Although the investigation of enzymatic hydrolysis with model substrates covers only a part of the total hydrolytic activities, the magnitude of carbon and nitrogen release from Trichodesmium colonies by enzyme activities was tentatively calculated. Values of potential PON and POC release by bacterial enzyme activity were calculated from PON and POC stocks of Trichodesmium colonies and the hydrolysis rate of proteins and carbohydrates (Hoppe et al. 1993). A theoretical $\mathrm{C}$ and $\mathrm{N}$ release between 30.52 and $1086.32 \mathrm{ng} \mathrm{C} \mathrm{h}^{-1}$ colony $^{-1}$ and between 4.56 and $209.25 \mathrm{ng} \mathrm{N} \mathrm{h}^{-1}$ colony ${ }^{-1}$ was calculated. Given 7 colonies $\mathrm{l}^{-1}$ in our investigations, between 214 and $7460 \mathrm{ng} \mathrm{C} \mathrm{h}^{-1}$ and between 32 and $1465 \mathrm{ng} \mathrm{N} \mathrm{h}^{-1}$ could be hydrolyzed by enzymatic activities of the attached bacteria and potentially supplied to the surrounding water.

In summary, our results support the thesis that attached bacteria play an active role in the degradation of Trichodesmium colonies and the release of low molecular weight substances into the surrounding water This process is one possibility for the transformation of new nitrogen introduced by $\mathrm{N}_{2}$-fixation in nutrient depleted subtropical and tropical waters, but it is limited by the low average abundance of colonies in the surface water.

Acknowledgements. This work was supported by DFG grant Na 285/1-1 I am grateful to E. Carpenter and D. Capone for the chance to take part in the cruise of RV 'Gyre' and their continuous support during the cruise. I thank the crew of RV 'Gyre' for their good assistance during the work, and $\mathrm{K}$. Lochte for intensive discussions during the preparation of the manuscript. This is IOW publication no. 233

\section{LITERATURE CITED}

Alldredge AL (1993) Production of heterotrophic bacteria inhabiting marine snow. In: Kemp PF, Sherr BF, Sherr EB, Cole JJ (eds) Handbook of methods in aquatic microbial ecology. Lewis Publishers, Boca Raton, p 531-537

Alldredge AL, Cole J, Caron JA (1986) Production of heterotrophic bacteria inhabiting organic aggregates (marine snow) from surface waters. Limnol Oceanogr 31:68-78

Azam F. Smith DC (1991) Bacterial influence on the variability in the ocean's biogeochemical state: a mechanistic view. In: Demers $S$ (ed) Particle analysis in oceanography. NATO ASı Series O27, Berlin, p 213-235

Azam F, Smith DC, Carlucci F (1992) Bacterial transformation of organic matter in the Southern California Bight. Prog Oceanogr 30:151-166

Bell RT (1993) Estimating production of heterotrophic bacterioplankton via incorporation of tritiated thymidine. In: Kemp PF, Sherr BF, Sherr EB, Cole JJ (eds) Handbook of methods in aquatic microbial ecology. Lewis Publishers, Boca Raton, p 495-503

Bergman B, Carpenter EJ (1991) Nitrogenase confined to 
randomly distributed trichomes in the marine cyanobacterium Trichodesmium thiebauti. J Phycol 27:158-165

Borstad GA, Glower FR, Carpenter EJ (1993) Development of algorithms for remote sensing of Trichodesmium blooms. In: Carpenter EJ, Capone DG, Rueter J (eds) Marine pelagic cyanobacteria: Trchodesmium and other diazotrophs. Kluwer Academic Publishers, Dordrecht, p 9-28

Borstad LE (1978) A qualitative and quantitative examination of bacteria associated with Trichodesmium species near Barbados. MSc thesis, McGill University, Montreal

Capone DG, Ferrier MD. Carpenter EJ (1994) Amino acid cycling in colonies of the planktonic marine cyanobacterium Trichodesmium thiebautii. Appl Environ Microbiol 60:3989-3995

Capone DG, O'Neil JM, Zehr J, Carpenter EJ (1990) Basis for diel variation in nitrogenase activity in the marine planktonic cyanobacterium Trichodesmium thiebautii. Appl Environ Microbiol 56:3532-3536

Carpenter EJ, Price EJ (1977) Nitrogen fixation, distribution, and production of Oscillatoria (Trichodesmium) spp. in the western Sargasso and Caribbean Seas. Limnol Oceanogr $22: 60-72$

Carpenter EJ, Romans K (1991) Major roie of the cyanobacterium Trichodesmium in nutrient cycling in the North Atlantic Ocean. Science 254:1356-1358

Chin-Leo G, Kirchman DL (1988) Estimating bacterial production in marine waters from the simultaneous incorporation of thymidine and leucine. Appl Environ Microbiol 54:1934-1939

Cho BC, Azam F (1990) Biogeochemical significance of bacterial biomass in the ocean's euphotic zone. Mar Ecol Prog Ser 63:253-259

Chrost RJ (1991) Environmental control of the synthesis and activity of aquatic microbial ectoenzymes. In: Chrost RJ (ed) Microbial enzymes in aquatic environments. SpringerVerlag, New York, p 29-59

Chrost RJ, Overbeck J (1990) Substrate-exoenzyme interaction: significance of $\beta$-glucosidase activity for glucose metabolism by aquatic bacteria. Adv Limnol 34:93-98

Delille D (1993) Seasonal changes in the abundance and composition of marine heterotrophic bacterial communities in Antarctic coastal areas. Polar Biol 13:463-470

Fuhrman JA, Azam F (1982) Thymidine incorporation as a measure of heterotrophic bacterioplankton production in marine surface waters: evaluation and field results. Mar Biol 66:109-120

Gocke K (1977) Comparison of methods for determining the turnover times of dissolved organic compounds. Mar Biol 42:131-141

Griffith P, Shiah FK, Gloerson K, Ducklow HW, Fletscher M (1994) Activity and distribution of attached bacteria in Chesapeake Bay. Mar Ecol Prog Ser 108:1-10

Güde $\mathrm{H}$ (1988) Incorporation of ${ }^{14} \mathrm{C}$-glucose, ${ }^{14} \mathrm{C}$-amino acids and ${ }^{3} \mathrm{H}$-thymidine by different size fractions of aquatic microorganisms. Arch Hydrobiol Beih Ergeb Limnol 31. $61-69$

Hoppe HG (1983) Significance of exoenzymatic activities in the ecology of brackish water measurements by means of methylumbelliferyl-substrates. Mar Ecol Prog Ser 11: $299-308$

Hoppe HG (1991) Microbial extracellular enzyme activity: a new key parameter in aquatic ecology. In: Chrost RJ (ed) Microbial enzymes in aquatic environments. SpringerVerlag, New York, p 60-83

Hoppe HG (1993) Use of fluorogenic model substrates for extracellular enzyme activity (EEA) measurement of bacteria. In: Kemp PF, Sherr BF, Sherr EB, Cole JJ (eds) Hand- book of methods in aquatic microbial ecology. Lewis Publishers, Boca Raton, p 423-431

Hoppe HG, Ducklow H, Karrasch B (1993) Evidence for dependency of bacterial growth on enzymatic hydrolysis of particulate organic matter in the mesopelagic ocean. Mar Ecol Prog Ser 93:277-283

Hoppe HG, Kim SJ, Gocke K (1988) Microbial decomposition in aquatic environments: combined process of extracellular enzyme activity and substrate uptake. Appl Environ Microbiol 54:784-790

Jonas RB, Tuttle JH, Stoner DL, Ducklow H (1988) Dual-label radioisotope method for simultaneously measuring bacterial production and metabolism in natural waters. Appl Environ Microbiol 54:791-798

Kirchman DL (1983) The production of bacteria attached to particles suspended in a fresh water pond. Limnol Oceanogr 28:858-872

Kirchman DL (1993) Leucine incorporation as a measure of biomass production by heterotrophic bacteria. In: Kemp PF, Sherr BF, Sherr EB, Cole JJ (eds) Handbook of methods in aquatic microbial ecology. Lewis Publishers, Boca Raton, p 509-512

Kirchinan DL, Keil RG, Simon M, Welschmeyer NA (1993) Biomass and production of heterotrophic bacterioplankton in the oceanic subarctic Pacific. Deep Sea Res 40:967-988

Middelboe M. Sondergaard M, Letarte Y, Borch NH (1995) Attached and free living bacteria: production and polymer hydrolysis during a diatom bloom. Microb Ecol 29:231-248

Münster U (1991) Extracellular enzymactivity in eutrophic and polyhumic lakes. In: Chrost RJ (ed) Microbial enzymes in aquatic environments. Springer-Verlag, New York, p $96-122$

Ohuki K, Fujita Y (1988) Aerobic nitrogenase activity measured as acetylene reduction in the marine non-heterocystous cyanobacterium Tnchodesmium spp. grown under artificial conditions. Mar Biol 98:111-114

O'Neil JM, Roman MR (1992) Grazers and assoziated organisms of Trichodesmium. In: Carpenter EJ, Capone DG, Rueter J (eds) Marine pelagic cyanobacteria: Trichodesmium and other diazotrophs. Kluwer Academic Publishers, Dordrecht, p 61-74

Overbeck J (1991) Early studies on ecto- and extracellular enzymes in aquatic environments. In: Chrost RJ (ed) Microbial enzymes in aquatic environments. SpringerVerlag, New York, p 1-5

Paerl HW, Bebaut BM, Prufert LE (1989) Bacterial associations with marine Oscillatoria spp. (Trichodesmium spp.) populations: ecophysiological implications. J Phycol 25: $773-784$

Paerl HW, Prufert-Bebaut LE, Guo C (1994) Iron-stimulated $\mathrm{N}_{2}$-fixation and growth in natural and cultured populations of the planktonic marine cyanobacteria Trichodesmium spp. Appl Environ Microbiol 60:1044-1047

Pomeroy LR, Wiebe EWJ (1993) Energy sources for microbial food webs. Mar Microb Food Webs 7:101-118

Psenner R (1993) Determination of size and morphology of aquatic bacteria by automated image analysis. In: Kemp PF, Sherr BF, Sherr EB, Cole JJ (eds) Handbook of methods in aquatic microbial ecology. Lewis Publishers, Boca Raton, p 339-346

Romans K, Carpenter EJ, Bergman B (1994) Buoyancy regulation in the colonial diazotrophic cyanobacterium Trichodesmium tenue: ultrastructure and storage of carbohydrate, polyphosphate, and nitrogen. J Phycol 30:935-942

Siddiqui PJA, Carpenter EJ, Bergman B (1993) Trichodesmium: ultrastructure and protein localization. In: Carpenter EJ, Capone DG, Rueter J (eds) Marine pelagic cyano- 
bacteria: Trichodesmium and other diazotrophs. Kluwer Academic Publishers, Dordrecht, p 9-28

Simon M, Alldredge AL, Azam F (1990) Bacterial carbon dynamics in marine snow. Mar Ecol Prog Ser 65:205-211

Simon M, Azam F (1989) Protein content and protein synthesis rates of planktonic marine bacteria. Mar Ecol Prog Ser $51: 201-213$

Smith DC, Simon M, Alldredge AL, Azarn F (1992) Intense hydrolytic enzyme activity on marine aggregates and implications for rapid particle dissolution. Nature 359: $139-142$

Smith DC, Steward GF, Long RA, Azam F (1995) Bacterial

This article was submitted to the editor mediation of carbon fluxes during a diatom bloom in a mesocosm. Deep Sea Res II 42:75-97

Turley CM (1992) Formation, vertical flux and remineralization of aggregates in the ocean: a short revue. Arch Hydrobiol Beih Ergeb Limnol 37:155-163

Wetzel RG (1991) Extracellular enzymatic interactions: storage, redistribution, and interspecific communication. In: Chrost RJ (ed) Microbial enzymes in aquatic environments. Springer-Verlag, New York, p 6-29

Zehr J (1995) Nitrogen fixation in the sea: why only Trichodesmium. In: Joint $J$ (ed) Molecular ecology of aquatic microbes. NATO AS Ser G: Ecol Sci 38:335-364

Manuscript first received: September 11, 1995

Revised version accepted: April 4, 1996 